\title{
Bringing human rights home: refugees, reparation, and the responsibility to protect
}

\section{James Souter}

Human rights, it is often observed, have become a common global language for making moral claims. One consequence of this is that there is a huge range of ways in which states, organisations and other actors draw on, invoke and mobilise human rights in different locations and contexts. The vast array of campaigns, treaties, laws and policies which fall under the umbrella of human rights means that human rights talk will be continually contested and, to some extent, fragmented, contradictory, and inconsistent. In Richard Wilson's phrase, human rights discourse will remain strongly marked by 'ideological promiscuity' (Wilson 2006). Given that human rights talk and practice are partly shaped by power, these inconsistencies will inevitably, at least to some degree, reflect power relations and dominant interests within and across states.

The existence of inconsistencies in some of the ways in which human rights are framed and put into practice has become more and more apparent to me in the years since I completed the MA in Understanding and Securing Human Rights in 2009. Liberal democratic states, such as the UK, profess their strong commitment to human rights principles. However, such states seem to tend towards the view that much of the business of human rights protection is something that should, or even can, only or mainly be provided beyond their borders. As Dan Bulley $(2010,43)$ has discussed, debates in such states often construct the 'human' in human rights as a subject which can 'only be saved close to its territorially qualified home', placing human rights squarely within the realm of foreign policy. When it comes to opening up the state to refugees, however, this commitment to human rights can come dangerously close to evaporating, given the range of measures used by Western states to prevent the arrival of asylum seekers and to limit the numbers of refugees they protect. This, it appears to me, is evident when we consider both efforts to achieve reparation and accountability for the harms suffered by refugees, and the ways in which states have framed the 'responsibility to protect' and sought to put it into practice. For the promise of human rights to be truly realised, I 
will suggest, reparation for refugees and the responsibility to protect need to be fully 'brought home' to liberal democratic states and linked to the practice of granting asylum to refugees.

\section{Reparation and refugees}

Reparation - whether in the form of restitution, compensation or satisfaction - is affirmed in international human rights treaties, and by the UN General Assembly, which adopted the Reparations Guidelines in 2005. ${ }^{1}$ Article 2 of the International Covenant on Civil and Political Rights (1966), for instance, lays down a right to 'an effective remedy' for violations of the human rights therein. Refugees, fleeing as they often do from severe violations of human rights and being subjected to serious harm during perilous journeys, are clearly entitled to such reparation. However, where reparation has been linked to refugee protection in theory and practice, it has largely been in relation to refugees' states of origin, and in the context of their repatriation (e.g. Bradley 2013; Cantor 2011). This is partly appropriate, for many of the harms of displacement are perpetrated by refugees' states of origin or by non-state actors within those states, and voluntary repatriation and reparations processes within these states - such as compensation, property restitution or truth-telling - can be the most fitting way of remedying the harms that refugees suffer.

It is a mistake, however, to assume that this is always the case. The static conception of protection as something that is possible only at, or near to, home has been reflected in what B.S. Chimni $(1998,360)$ has dubbed an 'internalist' approach to the causes of forced migration, which assumes that refugees' states of origin are entirely or mainly responsible for refugees' flight. Yet this internalist view ignores the clearly external causes of many contemporary cases of forced migration, whether as a result of military interventions, support for oppressive regimes, or the imposition of damaging economic policies. Interventions by Western states in Vietnam, Kosovo, Iraq and Libya in the past half-century, for instance, have produced huge numbers of refugees.

Once these external causes of displacement are brought into view, it becomes much less clear why reparation is something that is owed only within refugees' states of origin. As I have argued elsewhere, reparation for refugees is at times owed by states in the form of asylum (Souter 2014). When it comes to responsibilities towards refugees, the principle of reparation is often as applicable to refugees' host states as it is to their states of origin. There is, however, little evidence that the implications of the principle of reparation for

1 United Nations General Assembly (2005), Basic Principles and Guidelines on the Right to a Remedy and Reparation for Victims of Gross Violations of International Law and Serious Violations of International Humanitarian Law, UN Doc. A/RES/60/147 (21 March 2006), available at http://www.un.org/ga/search/view_doc.asp?symbol=A/ RES/60/147 (accessed 27 August 2015). 
asylum are recognised by states, save for a few isolated initiatives. In any case, these have tended to prioritise refugees who have assisted external states in their interventions, such as Iraqi and Afghan translators and interpreters who have worked for the US and UK, rather than offering asylum as reparation more broadly to those displaced by the receiving state's own actions.

\section{The responsibility to protect}

While refugee protection has been an important part of the human rights culture that has developed since World War Two, humanitarian intervention has remained a more controversial means of potentially upholding human rights in grave humanitarian emergencies. Drawing on existing human rights and humanitarian law, states unanimously agreed at the UN General Assembly in 2005 that they bear a 'responsibility to protect' (R2P) populations from genocide, ethnic cleansing, war crimes and crimes against humanity. This is primarily a responsibility of states to protect their own citizens, but it also involves assisting other states to fulfil their R2P, as well as, in the language of the World Summit Outcome Document, taking 'collective action, in a timely and decisive manner' when states are 'manifestly failing' to protect their populations from these four crimes. ${ }^{2}$ This may, but need not necessarily, involve military intervention.

As with the matter of reparation for refugees, R2P is generally viewed in liberal democratic states primarily as a foreign policy issue. In other words, although R2P has its roots in the same human rights tradition as refugee protection and reparation, they are not generally viewed holistically. While the tendency to conflate $\mathrm{R} 2 \mathrm{P}$ with military intervention to protect human rights has been dwindling in recent years, and a wider range of preventive activities - including, for instance, early-warning systems alerting states to impending atrocities - have been placed under the banner of R2P, it is nevertheless still predominantly viewed as something that 'we' do 'over there', in far-off states wracked by violence.

Yet the implications of R2P for states' asylum policies are not difficult to make out. When atrocities are imminent or are already being committed, a very frequent response by people at risk is to flee. $\mathrm{R} 2 \mathrm{P}$ is meant to protect individuals at risk from these atrocities, and an obvious means of doing so is through offers of asylum (Barbour and Gorlick 2008; Welsh 2014). While there is a strong case for seeing asylum as a core element of R2P as a matter of course, making this linkage becomes even more important when the traditional understanding of $\mathrm{R} 2 \mathrm{P}$ as humanitarian intervention is an obstacle to the delivery of effective

2 United Nations General Assembly (2005), World Summit Outcome Document, 15 September, UN Doc. A/RES/60/1 (24 October 2005), paras. 138 and 139, p. 30, available at http://www.un.org/womenwatch/ods/A-RES-60-1-E.pdf (accessed 27 August 2015). 
protection to those at risk. Military action is not only dangerous - risking as it does inflaming already volatile situations yet further and creating a fresh round of refugees who are owed reparation - but it is not always politically possible, given that it may be vetoed at the UN Security Council, or voted down in national parliaments, as we have seen in relation to the on-going crisis in Syria.

The international community's inaction in the face of atrocities committed as part of the Syrian civil war since 2011 has led some commentators to point to the failure - or even untimely death - of R2P. Yet this view betrays an overly narrow understanding of what R2P is and entails. Only if R2P is solely a matter of foreign policy does the current impasse over the crisis in Syria signify R2P's demise. In response to this deadlock, states can approach R2P creatively and make the obvious links with the alternative of asylum (Gilgan 2015). Rather than leaving the responsibility to protect Syrian refugees to already overburdened neighbouring states, such as Turkey, European states can partly discharge their own R2P to many of those refugees who are now in any case seeking to enter Europe in large numbers.

Linking R2P with the principle of reparation can also potentially help to make some headway in making R2P's vision a reality. When R2P falls on other states to step in when states are 'manifestly failing' to fulfil their primary responsibility to their citizens, the fact that $\mathrm{R} 2 \mathrm{P}$ is seen by states as a general responsibility, that is shared equally among all states, creates a collective action problem. This view of R2P as a diffuse, shared responsibility allows each state to claim to uphold R2P while not seeing it as its specific role to take action in any given situation. Assigning a special responsibility to protect to a particular state or states on the basis of the principle of reparation when there is a case for doing so can help to overcome this problem, and to ensure that effective action is taken to protect those at risk from atrocities (see Pattison 2010; Tan 2006). For instance, as I have recently argued in an article with Jason Ralph, given that the 2003 invasion of Iraq destroyed the Iraqi state and rendered Iraqis highly vulnerable to external shock, which then materialised in the form of Islamic State in 2014, it is reasonable to argue that the US and other states which took part in the invading coalition, such as the UK and Australia, bear a 'special responsibility to protect' that is more demanding than a merely general responsibility shared with all states, and includes an obligation to offer asylum to a larger number of Iraqi refugees (Ralph and Souter 2015).

\section{Thinking 'outside the box'}

There is a broader point to be made here about how academics study human rights, and the role of political frameworks and policy categories in their research. Many scholars in human rights and refugee studies are motivated by a desire to alleviate suffering and injustice, and are concerned to ensure that their research has a positive impact on efforts to protect human rights, 
by raising awareness or influencing policy. In order to gain policy relevance, understandably academics often speak in the language that politicians and policy-makers understand. In doing so, however, there is a danger that they replicate and reinforce artificial divisions between elements of human rights law, policy and practice, such as those concerning reparation, asylum and R2P that I have highlighted here, that are more reflective of states' interests than the needs of those at risk or the situations in which they find themselves. There is a danger that the uncritical use of policy categories can distort research on human rights and refugees, and limit its progressive potential (see Bakewell 2008; Turton 2003). Scholars, for instance, have largely left unchallenged the view that reparation for refugees is a matter for refugees' states of origin, or the idea that R2P is solely or largely a foreign policy issue. The desire for policy relevance needs to be coupled with a critical approach to policy categories and frameworks. Only then can academics and researchers help to overcome the inconsistencies and blind spots that currently beset some of the current efforts to understand and promote human rights.

\section{Bibliography}

Bakewell, O. (2008) 'Research beyond the categories: the importance of policy irrelevant research into forced migration', Journal of Refugee Studies 21 (4), pp. 432-453.

Barbour, B. and B. Gorlick (2008) 'Embracing the "responsibility to protect": a repertoire of measures including asylum for potential victims', International Journal of Refugee Law 20 (4), pp. 533-66.

Bradley, M. (2013) Refugee Repatriation. Justice, Responsibility and Redress (Cambridge: Cambridge University Press).

Bulley, D. (2010) 'Home is where the human is? Ethics, intervention and hospitality in Kosovo', Millennium: Journal of International Studies 39 (1), pp. 43-63.

Cantor, D. J. (2011) 'Restitution, Compensation, Satisfaction: Transnational Reparations and Colombia's Victims' Law', UNHCR Working Paper No. 215. (Geneva: UNHCR).

Chimni, B. S. (1998) 'The geo-politics of refugee studies: a view from the South', Journal of Refugee Studies 11 (4), pp. 350-374.

Gilgan, C. (2015) Lost in Translation? The Responsibility to Protect, the UK and Syrian Refugees. Presented at the Postgraduate Research Conference, School of Politics and International Studies, University of Leeds, 10 June.

Pattison, J. (2010) Humanitarian Intervention and the Responsibility to Protect. Who Should Intervene? (Oxford: Oxford University Press). 
Ralph, J.G. and J. Souter (2015) 'A special responsibility to protect: The UK, Australia, and the rise of Islamic State', International Affairs 91 (4), pp. 709-724.

Souter, J. (2015) 'Why the UK has a special responsibility to protect its share of refugees', The Conversation (15 May 2015).

Souter, J. (2014) 'Towards a theory of asylum as reparation for past injustice', Political Studies 62 (2), pp. 326-42.

Tan, K-C. (2006) 'The Duty to Protect', in T. Nardin and M. S. Williams (eds.), NOMOS XLVII: Humanitarian Intervention (New York: New York University Press).

Turton, D. (2003) 'Conceptualising forced migration', Refugee Studies Centre Working Paper No. 12 (Oxford: Refugee Studies Centre).

Welsh, J. (2014) 'Fortress Europe and the R2P: framing the issue', presented at The Lampedusa Dilemma: Global Flows and Closed Borders. What

Should Europe Do?, European University Institute, Florence, Italy, 17-18 November 2014.

Wilson, R.A. (2006) 'Afterword to "Anthropology and Human Rights in a New Key": the social life of human rights', American Anthropologist 108 (1), pp. 77-83. 